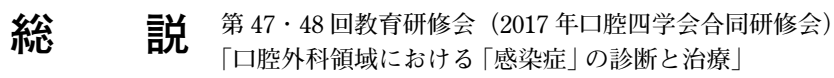

\title{
グローバリゼーション時代の感染症
}

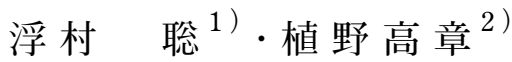

\section{Infectious disease in globaltimes}

\author{
UKIMURA Akira $^{1)} \cdot$ UENO Takaaki $^{2)}$
}

\begin{abstract}
National Action Plan on Antimicrobial Resistance was developed in 2016 accordingly by the Ministerial Meeting in Japan, because the inappropriate use of antimicrobials has been indicated as the background to the global spread of antimicrobial resistance. National Action Plan is structured around goals in the following six areas: (1) Public Awareness and Education, (2) Surveillance and Monitoring, (3) Infection Prevention and Control, (4) Appropriate Use of Antimicrobials, (5) Research and Development, and (6) International Cooperation. It is required to adopt a global "One Health" approach, which addressed both human and animal health together. We reported an outbreak of multi-drug resistance pseudomonas aeruginosa with a new antimicrobial resistant gene, GES-5, and we hypothesized that cross-contamination due to poor hand hygiene was the main cause of transmission and that sharing unsanitary portable oral-care devices may have contributed to transmission between patients. Standard precautions are applicable to all settings in which dental treatment is provided.
\end{abstract}

Key words: one health (ワンヘルス)， antimicrobial resistance (薬剤而性)， standard precautions（標準予防策）

\section{緒 言}

今はまさにグローバリゼーション時代となり，感染症も 国家を超えたグローバリゼーション時代に入ったとされて いる ${ }^{1)}$ ，感染症に関しては 20 世紀終盤以降, 新興の感染 症, 例えば重症急性呼吸器症候群 (SARS), 高病原性卜リ インフルエンザ, エボラ出血熱, ジカウイルス感染症など が次々と出現してきた。疾患の面からみると，現在我々は 1. 新興・再興感染症, 2. エイズ, マラリア, 結核という患 者数が多く, 対策の困難な感染症, 3. 薬剤耐性菌の 3 つの 課題に直面しているといえる.

感染症のグローバリゼーションの要因は第一に人口増加 である。世界の人口は産業革命以降増加し, 大都市が形成 され, 人が密集して住むようになったことが感染者数の増 加に密接に関連していると考えられる. エボラ出血熱, ジ

1) 大阪医科大学附属病院感染対策室

(主任：浮村 聡教授)

2) 大阪医科大学口腔外科学教室 (主任：植野高章教授)

${ }^{1)}$ Infection Control Center, Osaka Medical College Hospital (Chief: Prof. UKIMURA Akira)

${ }^{2)}$ Department of Dentistry and Oral Surgery Infectious Disease in Globaltimes (Chief: Prof. UENO Takaaki)
カウイルス感染症は, ジャングルや島々に限られていた 感染症が都市で流行したことが要因になっているといえ る。第二の要因は交通の発達である. SARS はジェット機 による大量輸送が瞬く間に世界中に感染症を拡散させた代 表的な例といえる。日本における 20 代女性の梅毒の著増 と人の移動の関連が推定されている. 第三の要因は食の産 業革命といえる。腸管出血性大腸菌感染症と加工肉, 伝染 性海綿状脳症と草食動物への肉骨粉の使用, 音産業や水産 業における抗菌薬の使用と細菌の耐性化などがこの要因に 関連した代表的事例といえる。そしてとくに薬剤耐性菌を 論じるにおいてはすでに人のみを対象としているだけでは 片手落ちの時代となり, 人の衛生, 家畜の衛生, 環境の衛 生の関係者が連携して対策に取り組むべきであるといった “One Health”の理念を普及・推進させることが求められ ている(図 1 $)^{2}$ ).

\section{1. 薬刘耐性 (Antimicrobial resistance, AMR) アクションプラン}

抗菌薬の不適切な使用を背景にして, 薬剤耐性菌が世界 的に増加する一方, 新たな抗菌薬の開発は減少傾向にあ り，国際的に問題となっている ${ }^{3)}$. 2014 年にイギリス政 


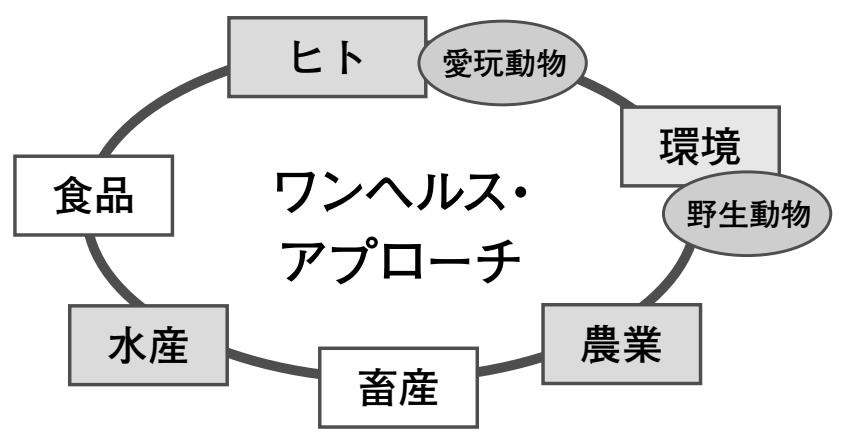

図 1 ワンヘルス・アプローチ

http://www.mhlw.go.jp/file/06-Seisakujouhou-10900000Kenkoukyoku/0000120769.pdf から引用

府とウェルカムトラストは 2013 年時点での AMR に起因 する死亡者数は低く見積もって 70 万人と報告している ${ }^{4)}$. しかし薬剤耐性菌が現在のペースで増加し, 我々が何も対 策を取らなかった場合には 2050 年には全世界で推定 1,000 万人の死亡者が出るとし，これは現在の癌による死亡者数 の 820 万人を凌駕する驚異的な数字である. 2015 年の世 界保健総会では薬郕耐性 (Antimicrobial resistance, AMR) に関するグローバル・アクション・プランが採択された. これを受け厚生労働省は伊勢志摩サミット直前に AMR ア クションプランを策定した ${ }^{2)}$. AMRアクションプランは 関係省庁・関係機関等がワンヘルス・アプローチの視野に 立ち，共同して集中的に取り組むべき内容をまとめたもの である。計画は今後 5 年間 $(2016 〜 2020$ 年) において $6 つ$ の分野，すなわち 1. 普及啓発・教育, 2. 動向調査・監視, 3. 感染予防・管理, 4. 抗微生物剂の適正使用, 5. 研究開 発・創薬，6. 国際協力に扎いてこれらに関する「目標」や， その目標ごとに「戦略」および「具体的な取組」等を盛り込 むとされている ${ }^{5}$ )。（図 2,3）このうち 1.2.3.4 は筆者ら感 染制御に関する仕事に従事するものにとっての日常業務と いえる。またこの AMR アクションプランには耐性菌と抗菌 薬使用量についての具体的な成果目標が定められている.

\section{2. 薬剤耐性菌の現状把握 : 市中感染が高度耐性菌で発症する時代}

フレミングによりカビがペニシリンを産生していること が発見されたのが 1928 年で翌年にそのことが発表された。 ペニシリンが市場に出る前からペニシリン耐性菌は存在 し，抗菌薬の歴史は耐性菌の歴史であった ${ }^{2)}$ 。ただし抗菌 薬が次々と開発されていた時代には耐性菌はさほど大きな 問題となっていなかった。その理由として例えばメチシリ ン耐性黄色ブドウ球菌（MRSA）が出現しても抗 MRSA薬 が次々に開発されていた背景があったからともいえる。し
かし今や新規の抗菌薬の開発は急ブレーキがかかった状況 にある ${ }^{3)}$. したがって現在使用しうる抗菌薬の有効性を少 しでも長く維持する方策が必要とされる。

さらにMRSA が問題となった 20 世紀終盤には市中感染 症は感受性良好菌，院内感染症においてのみ耐性菌が検出 されるのが通常であった。また耐性菌の多くは日和見感染 の原因の弱毒菌であった。しかし現在は市中感染症の原因 菌が高度耐性菌である時代が始まったと考えられる。耐性 が生じるメカニズムは突然変異によるものと耐性遺伝子獲 得によるものに大別できる。他に抗菌薬の入る穴 (ポーリ ン) や抗菌薬をくみ出すポンプの変化によるものもあり, これらの機序による耐性化は緑膿菌などで良く認められ る。また突然变異によるものは耐性度もあまり高くないこ とが多く伝達性も低いことが多い。しかし, 耐性遺伝子獲 得によるものは耐性度が高く, 遺伝子が伝達性をもつこと が予測され，とくにプラスミドによるものは異なった菌種 間でも伝播し問題である．現在市中で認められる代表的な 而性菌は ESBL 産生菌やカルバペネム耐性腸内細菌科細菌 (Carbapenem-Resistant Enterobacteriaceae, CRE) などで, これらはまさに耐性遺伝子がプラスミドを介して伝播する 耐性菌である。とくに CREに関しては，「悪夢の耐性菌」 として米国疾病対策予防センターが警告を発し6)，日本で も CREによるアウトブレイク事例をきっかけに7)，2014 年 9 月 19 日に感染症法施行規則 (省令) が改正され，「力 ルバペネム耐性腸内細菌科細菌感染症」が，5類全数報告 疾患に指定され，全国すべての医療機関で該当する感染症 の患者を診断した場合には保健所に届け出ることが義務付 けられた。CREの問題点は以下の点にある。1. CRE は高 度な耐性を有し，治療薬が限定され，致死率が高い。2. 日 本に多いカルバペネム耐性遺伝子の IMP 型には IMP-1 と IMP-6 があるが，IMP-6 産生菌はイミペネムに対し「感性」 と判定されることが多いため, 通常の検査で見逃される可 能性も否定できず，ステルス型ともいわれる．3. 腸内細菌 科の代表的な菌の大腸菌, 肺炎桿菌, エンテロバクター属, シトロバクター属などはまさに腸内常在菌であり，腸内に 保菌すると除菌がきわめて困難であり，環境污染や健常人 の保菌者の拡大が懸念される. 4. IMP はプラスミド伝播す るため異なる菌種でも水平伝播のことがあり, アウトブレ イクの判断に遅れが生じる懸念がある.

実際に他国では肺炎桿菌の 70\%が CREである国もある. 一方で日本に打ける $\mathrm{CRE}$ は $0.1 〜 0.2 \%$ とされ, AMRアク ションプランには CREの検出率の抑制に関する数值目標と して現状維持の $0.1 〜 0.2 \%$ という数值が示されている ${ }^{2)}$. しかしオムツ使用患者では $10 \%$ を超える検出率であった という報告もあり， CREによる感染症が市中発症する時 代が日本でも始まった可能性は否定できない，まずは行政 


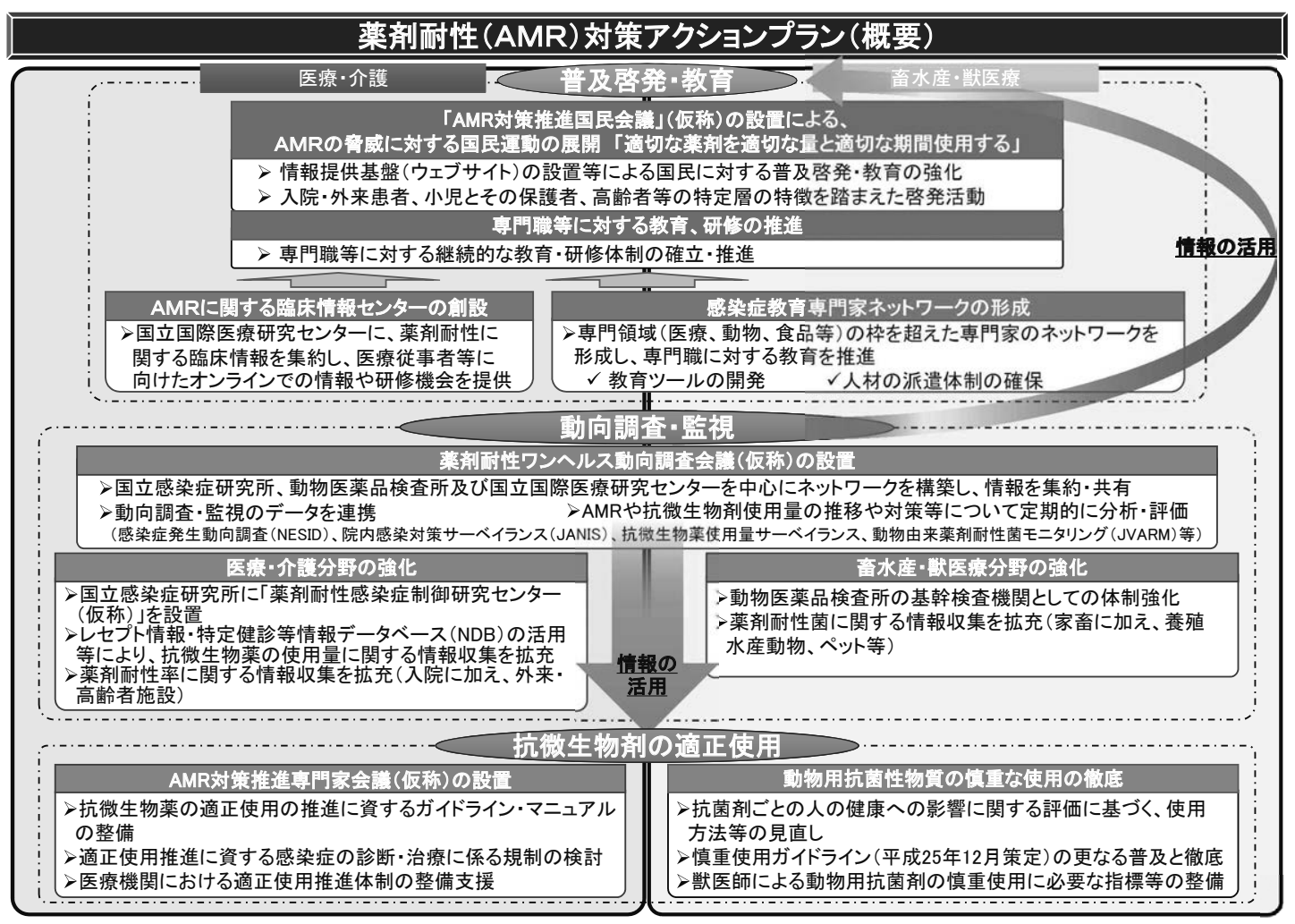

図 2 1. 普及啓発・教育, 2. 動向調査・監視, 4. 抗微生物剂

http://www.mhlw.go.jp/file/06-Seisakujouhou-10900000-Kenkoukyoku/0000120777.pdf から引用

\section{薬剤耐性(AMR) 対策アクションプラン (概要)}

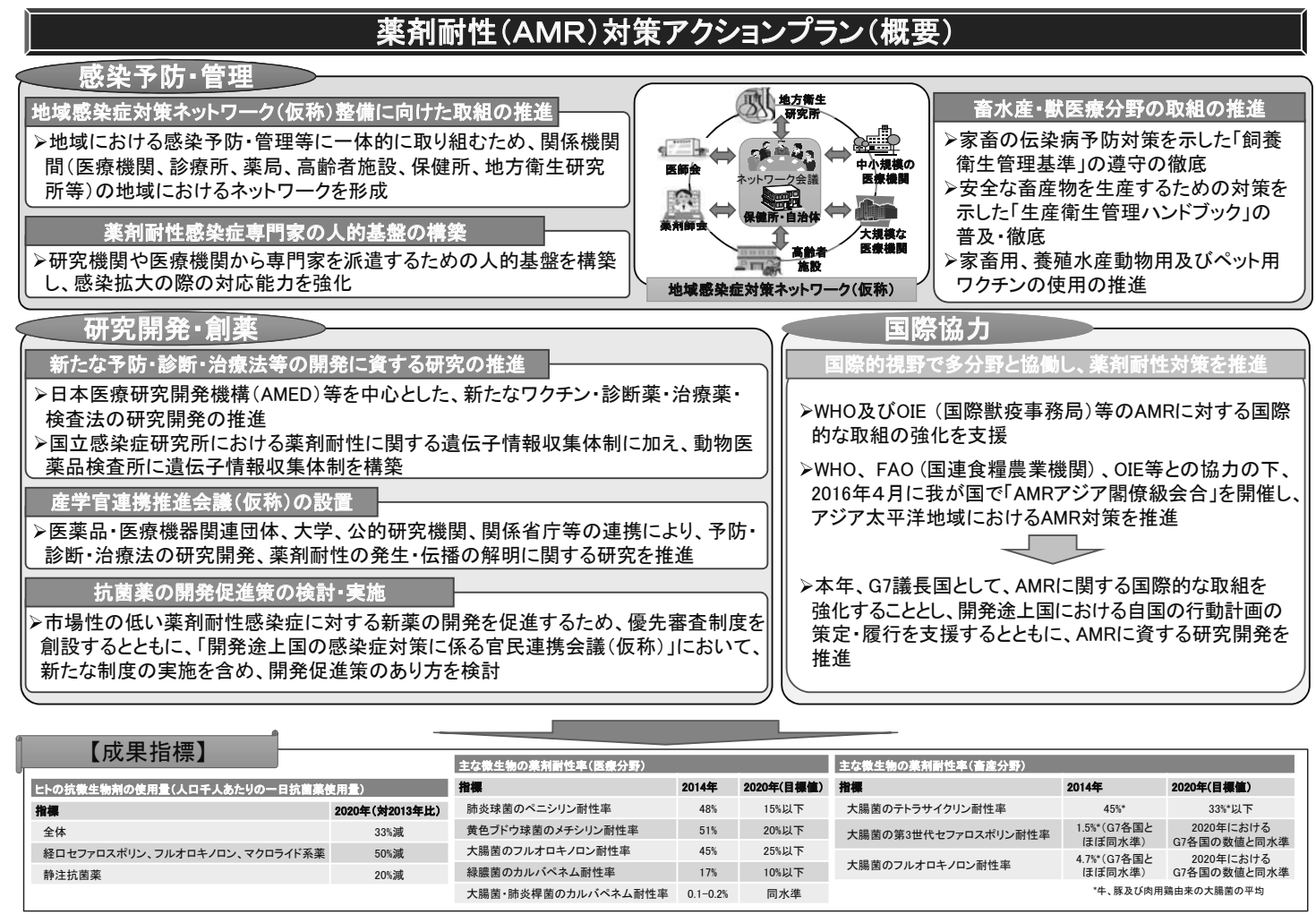

図 3 3. 感染予防 ·管理, 5. 研究開発・創薬, 6. 国際協力

http://www.mhlw.go.jp/file/06-Seisakujouhou-10900000-Kenkoukyoku/0000120777.pdf から引用 
と地域の基幹病院が協力して CRE の実態調査を進めるとと もに, 感染制御に関連した対策を進めていく必要がある.

\section{3. 地域の中小病院での本邦初の 耐性菌による院内感染事例}

大阪医科大学附属病院は中心となって地域の感染制御の レベルアップのための「北摂四医師会感染対策ネットワー ク」(70 万人医療圈の主要 26 病院, 総計約 4,000 床以上) を立ち上げた。穵の後 2013 年 12 月ネットワーク内の中小 規模の病院にて多剤而性緑膿菌 (Multi-drug resistant Pseudomonas aeruginosa, MDRP) によるアウトブレイクが発 生しマスコミで報道された。患者検体と環境から検出され た 16 株の MDRP 遺伝子解析が, 大阪府公衆衛生研究所に より実施され，その結果はすべて同一の菌株で本邦初の 耐性遺伝子 GES-5による MDRPであった ${ }^{8,9)}$. しかしこ のMDRPは確かにカルバペネム，ニューキノロン，アミ ノ配糖体に関しては耐性であったが，アズトレオナムには 感受性があり，また第四世代セフェム系に関しては耐性か ら感受性まで感受性に差があった，すなわち，抗菌薬感受 性に関する表現型は株により異なっており，通常の感受性 検査のみでは同一株と認識することが困難で，また GES-5 というカルバペネマーゼを産生しているにも関わらず通常 細菌検查室で行う検出法ではカルバペネマーゼを検出する ことが困難であった．著者らのネットワークは保健所の依 頼を受け国立感染症情報センター, 大阪府公衆衛生研究所, 保健所, 第三者機関の専門家とともにとこのアウトブレイ クのコントロールを開始した。

今回のアウトブレイクにおいては，保健所の指導の下， 依頼を受けた多施設の対策チームが実際的な対策を実施し， その成果を評価チームが評価するという体制を構築して, アウトブレイクを収束させることができた。攵の内容は， 標準予防策ならびに感染経路別予防策の徹底, 啓発と情報 の共有，感染症診療支援など多岐にわたった，その後この 病院では 2 度この MDRPによる敗血症が発生したが, 著 者らは感染症診療支援として, アズトレオナムを含む抗菌 薬併用療法を行うように助言し， 2 度とも治癒させること ができた。また，地域に打ける耐性菌の広がりの監視体制 構築も重要な課題と考えられ, 著者らは地域の MDRPに おける GES-5 をもつ耐性菌の地域内の伝播状況を調査する ための遺伝子学的検討方法として, 各種カルバペネマーゼ である GES, OXA-48, IMP, VIM, KPC を同時に検出可能な マルチプレックス PCR 法 ${ }^{10)}$ による GES-5 の検出と緑膿菌 PCR-based open reading frametyping 法 (POT 法) ${ }^{11)}$ を用 いた．POT法は従来の標準的な方法であったパルスフィー ルド・ゲル電気泳動（PFGE）よりも容易で, 菌主幹で保有
状態にある遺伝子の読み取り枠 (open reading frame, ORF) をマルチプレックス PCR で検出し，その保有パターンに よって遺伝子型 (POT型) を決定し, 遺伝子が同一か否か の判定を行う方法である. POT 法は PFGEより安価かつ 短時間で実施でき,さらに遺伝子型を数值化し結果として 報告が可能であり，此較が容易であることが利点と考えら れる。午の結果この地域で認められた他の MDRP 株では GES-5 陽性株を認めず，今回の遺伝子型と同一の MDRP も認められなかった (図 4)。中小規模の病院では, 大病院 に比べ資源が限られているため, 実施および継続可能な対 策に制約があり，病院の状況に応じ適切な対策を決める必 要がある. 今回のような遺伝子的検索の必要な事例に扔い ては, より大きな規模の病院でも対応は困難と考えられる. 地域に抢ける多剤耐性菌の伝播を抑制するために，所轄保 健所と感染管理ネットワークが協力して, 而性菌のサーベ イランスと病院の状況に応じた感染対策が適切に行われて いるか否かの確認を今後も継続していくことは重要と考え られる。

このアウトブレイク拡大の 1 つの要因として，この病院 では柬科衛生士によるポータブルの口腔ケア用の装置を用 いた口腔ケアが行われていたが，その運用が感染対策上き わめて不適切であることが判明した。この装置はプラス チック製のデバイスを患者の口腔内に挿入して吸引を行い ながら，同じ装置に装備された電動歯ブラシなどを用いて 口腔ケアを行うものとなっている。このような装置自体が 本来個人使用とすべきものであり，少なくとも口腔内に挿 入するデバイスは個人使用とすべきと考えられる．またこ の事例では口腔内に挿入するデバイスの現場における一次 洗浄が問題と考えられた。医療施設では医療器具はディス ポーザブルとし，再利用しないのが理想的であるが，コス トの面からすべてでディスポーザブルとすることには無理 がある. 次のレべルとしては清潔なものと不潔となったも のとの経路は交叉せずワンウェイで運用されることが求め られる.すなわち病棟などの現場で行う一次洗浄は, 周辺 環境の污染を生むことからできるだけ洗浄, 消毒, 滅菌に 関しては中央化することが理想である。本事例では吸引の ため口腔内に挿入したデバイスを各病棟のシンクにて一次 洗浄したことによりシンクの耐性菌による污染と水平伝播 の拡大を招いた可能性が示唆された。

また本事例では標準予防策の重要性が再認識された。す べての医療の現場で感染対策のため, 標準予防策の実施が 求められている．標準予防策とは患者と医療従事者の双方 からの感染を防止するということであり，感染を防止する ために「すべての生体湿性物質は感染性があるものとして 扱う」ことが求められる.すなおちすべての患者の (1)血液, (2)汗を除くすべての体液, 分泌物, 排泄物, (3)粘膜，(4)損 
a

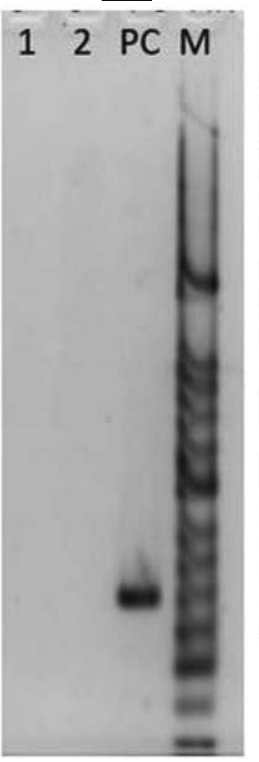

\section{$\mathrm{b}$}

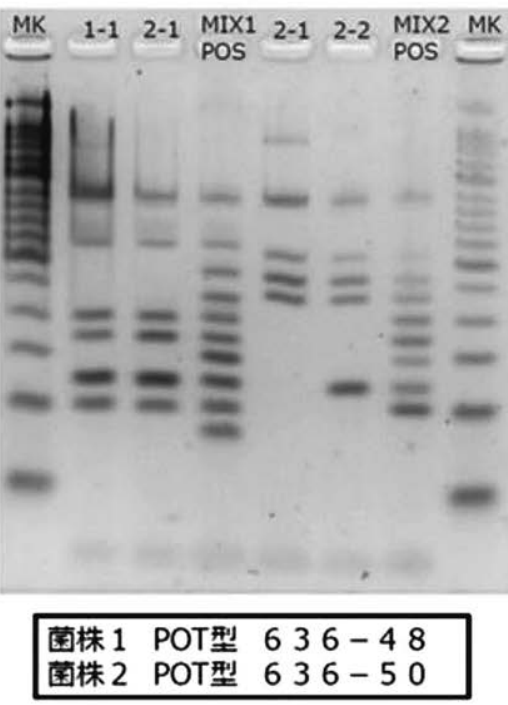

\begin{tabular}{|c|c|c|c|c|}
\hline \multirow{2}{*}{ Reaction1 } & \multicolumn{2}{|c|}{ Lane } & 1 & 2 \\
\hline & $\begin{array}{l}\text { P.aerugrinosa } \\
\text { positive }\end{array}$ & & & \\
\hline PCR PC & control & 506 & 1 & 1 \\
\hline POT1-1 & Islet-1 & 336 & 1 & 1 \\
\hline РОT1-2 & Islet-2 & 281 & 0 & 0 \\
\hline POT1-3 & Islet-3 & 235 & 0 & 0 \\
\hline POT1-4 & Islet-4 & 201 & 1 & 1 \\
\hline POT1-5 & Islet-5 & 175 & 1 & 1 \\
\hline РОT2-1 & VIM & 151 & 0 & 0 \\
\hline POT2-2 & Prophage-1 & 126 & 1 & 1 \\
\hline POT2-3 & Prophage-2 & 103 & 1 & 1 \\
\hline РОT2-4 & Prophage-3 & 85 & 0 & 0 \\
\hline \multirow[t]{2}{*}{ Reaction2 } & & Lane & & \\
\hline & $\begin{array}{l}\text { P.aerugrinosa } \\
\text { positive }\end{array}$ & & & \\
\hline PCR PC & control & 506 & 1 & 1 \\
\hline РОT1-6 & Islet-6 & 324 & 1 & 1 \\
\hline POT1-7 & Islet-7 & 271 & 1 & 1 \\
\hline POT1-8 & Islet-8 & 238 & 1 & 1 \\
\hline POT1-9 & Islet-9 & 204 & 0 & 0 \\
\hline POT $1-10$ & Islet-10 & 176 & 0 & 0 \\
\hline POT2-5 & Prophage-4 & 150 & 0 & 0 \\
\hline РОT2-6 & Prophage-5 & 124 & 0 & 1 \\
\hline POT2-7 & IMP & 105 & 0 & 0 \\
\hline \multirow{2}{*}{ 新POT型 } & & POT1 & 636 & 636 \\
\hline & & РОT2 & 48 & 50 \\
\hline
\end{tabular}

図 4 マルチプレックス PCR の結果, 緑膿菌 POT 法の結果と POT 番号

$\mathrm{a}$ ：マルチプレックス PCRの結果； マルチプレックス PCRのプライマーは文献 4 による [左から菌株 1 , 菌株 2 , GES 陽性コントロール株, M (分子量マーカー)].

b：緑膿菌 POT 法の結果；左から MK (分子量マーカー) , 1-1：菌株 1の POT 1 法, 2-1：緑膿菌の POT 法の結果は 今回の GES-5 産生菌は POT 番号 207-56 であり, 図に示す緑膿菌は 636-48 と 636-50 番となり POT 番号のみで遺 伝子が異なるという情報を共有できる. 菌株 2 の POT 1 法, 陽性コントロールの POT 1 法, 2-1: 菌株 2 の POT 1 法, 2-2：菌株 2 の POT 2 法, 陽性コントロールの POT 2 法, MK.

c：緑膿菌 POT 法の反応 1 と反応 2 の陽性産物の分子量と POT 番号の算出法.

傷した皮膚は感染の可能性があるものとして対応すること が求められている。しかし，耐性菌が検出された患者での 感染経路別予防策は実施されていたが，標準予防策の考え 方が浸透していなかったことが，アウトブレイクの最大の 要因と推定された。この事例からは医科に打ける感染対策 もまだまだ不十分な面があるが，柬科領域における感染対 策はさらに立ち遅れている現状が再認識された。

\section{4. 歯科領域での感染対策}

最近口腔ケアの実施により䛊嚥性肺炎の発症を抑制でき るというエビデンスが蓄積されている ${ }^{12)}$ 。また周術期に おける口腔ケアに対する管理料が算定されるようになり口 腔衛生管理が注目され, 口腔ケアが盛んに行われるように なってきた。しかし一方で例えばエアタービンなどが十分 な滅菌処理を行われず使用されている実態が新聞報道され るなど, 歯科口腔外科領域の診療現場では, 知識, コスト などの多くのハードルが存在し, 必ずしも十分な感染対策 が実施されている訳ではないと考えられる。そこで㐘科口 腔外科領域における感染対策のレベルアップのため, 最近 国公立大学附属病院感染対策協議会により㐘科における院
表 1 国公立大学附属病院感染対策協議会㐘科における 院内感染ガイドライン改訂第 2 版より抜粋 (一部改変)

1) 観血的治療

(1) 血液や体液などで衣服が污染される危険性がある場合 は，ガウンまたはエプロンを着用する (A II) .

(2) 血液や体液の飛散が予想される場合には, マスク, フェ イスシールド，ゴーグルを着用する (A II) .

(3)防護用具は処置ごとに交換する.

(6)観血的治療に使用する器具類は滅菌処置したものを用 いる.

(3)血液・体液で污染された環境表面は, 手袋をはめてぺー パータオルで肉眼的な污染を除去した上で, 次亜塩素 酸ナトリウムを用いて清拭消毒する.

2 ）観血的治療に準ずる治療

(1)個人防護具については観血的治療に準ずる.

内感染ガイドライン改訂第 2 版が作成されたのでその一部 を抜粋し, 紹介する (表 1) ${ }^{13)}$. ガイドラインではこのよ うに標準予防策の徹底が求められている。これらの対策を すべてで実施することが本来求められるべきではあるが, まずは院内感染の観点から, 過去の多剤耐性緑膿菌や CRE 


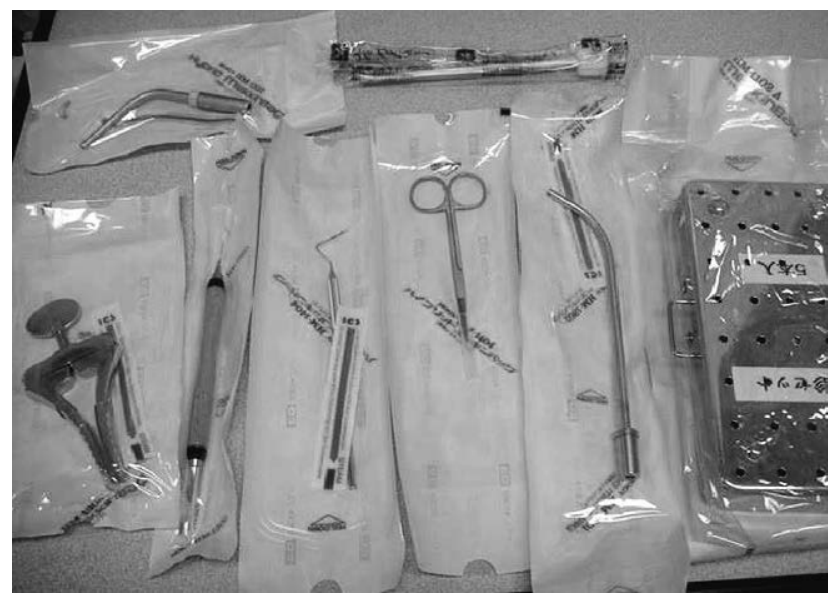

写真 1 感染対策を考慮した往診での器具のパッケージング

のアウトブレイク事例から ${ }^{7)}$ ，とくに注意すべき患者の例 を示す. 1. 入院患者, とくに抗菌薬や手術, 抗がん剂など の治療を受けた患者（とくにドレーン入れ替え, 腸瘻増設, 膵頭十二指腸切除術などが CREのリスク).2. 外来患者で 90 日以内に手術など濃厚な医療を受けた患者. 3. 海外で 濃厚な医療を受けた患者. 4. 咳など上気道症状のある患者, その環境．5.下痱をしている患者，その環境．などが挙げ られ, これらの患者に扔いてはとくに注意し, 器具の洗浄, 滅菌，消毒を適切に行い，適切に手指消毒を行い，適切に ガウン，手袋，ゴーグルを使用することが求められている と考えられる.

大阪医科大学における歯科診療と口腔ケアに関しては感 染対策に十分配慮しながら行われるように最近改革されつ つある。とくに標準予防策を徹底させるために手指消毒や 個人防護具の使用を徹底し, 病棟で用いる口腔ケア用品の パッキング (写真 1) などを行っている.

\section{5. 抗菌薬の適正化}

抗菌薬の適正使用とは起因菌と感染病巣に適した抗菌薬 を選択し有効な方法で投与することにより治療効果を高 め，耐性菌発生を抑制することをいう。しかし臨床の現場 では抗菌薬使用時に起因菌と感染病巣が特定されているこ とはまれであり，また柬科領域では培養実施も日常に行わ れている訳ではなく，本来の抗菌薬の適正使用にはいくつ かのハードルがあることがわかる。

そこで日常診療で避けるべき抗菌薬の不適正な使用につ いて列記する。1. 例えばウイルス性の感冒に対する抗菌薬 の使用に代表される本来無効な抗菌薬の使用. 2. 活動的な 炎症のない保菌状態に対する抗菌薬の使用. 3. 有効性の期 待できない選択と投与法, すなわち経口投与では吸収率の
低く組織移行の悪い抗菌薬の選択による耐性菌の誘導な ど.4. カルバペネムやニューキノロンなどの広域抗菌薬の 長期使用による緑膿菌の耐性化の誘導や, 結核菌に感受性 のあるニューキノロンの不適切な使用による結核診断の遅 れ。などが考えられる.

2013 年の日本の 1 日の抗微生物薬使用量は, 1,000 人あ たり 15.8 (Defined Daily Dose) と推定されており，欧州と の比較に沶いて, 決して多くはない状況である(図 5). し かし欧州で最も抗微生物薬使用量の少ないオランダでは, 日本の 3 分の 2 程度の使用量である ${ }^{2)}$ 。一方で, 日本の 経口抗菌薬の使用割合の特徴は, マクロライド系抗菌薬 (33\%) と，セファロスポリン系 $(27 \%$ 。そのうち 80\%は第 3 世代)，フルオロキノロン系薬 (19\%) の 3 系統が全使用 量の $80 \%$ 占めていることにある ${ }^{2)}$. 今回の AMRアクショ ンプランにおいてはこの 3 系統の抗菌薬使用量を半減し, さらに適正使用の推進により静注抗菌薬の使用量を $20 \%$ 削 減することで, 全抗微生物薬使用量を 3 分の 2 に減少させ たいという数值目標が掲げられている. 歯科口腔外科領域 での抗菌薬使用に扎いてはその対象となる菌は口腔内のグ ラム陽性球菌や嫌気性菌と考えられる。したがって苗科領 域においてもバイオアベイラビリティが低く，すなわち腸 管吸収が $30 \%$ 前後と低くかつ抗菌スペクトラムが広いこと から耐性化に関与する確率の高い第三世代セフェム系薬㓱 から，ペニシリン系への変換を考慮していくことが求めら れているといえる.

\section{結語}

今後医科と㐘科が連携し，アクションプランにおける第 一のステップ 1. 普及啓発・教育を始めに, 2 . 動向調查・ 監視，3. 感染予防・管理，4. 抗微生物剤の適正使用を実践 していく必要があると考えられる。

\section{謝辞}

本総説をご依頼いただいた (公社) 日本口腔外科学会専門医 制度研修カリキュラム委員長の近藤壽郎先生をはじめ関係の先 生方に深謝申し上げます。また同総説の要旨は第 47 回・48回 日本口腔外科学会教育研修会 (2017 年口腔四学会合同研修会) にて講演したものです。

本論文に関して，開示すべき利益相反状態はない.

\section{引用文 献}

1 ) 岩本愛吉：グローバリゼーションと感染症. 化療の 領域 22: 19, 2006.

2 ) 国際的に妿威となる感染症対策関係閣僚会議: 薬剤耐 性アクションプラン. 1-71 頁, 2016. http://www.mhlw. go.jp/file/06-Seisakujouhou-10900000-Kenkoukyoku 

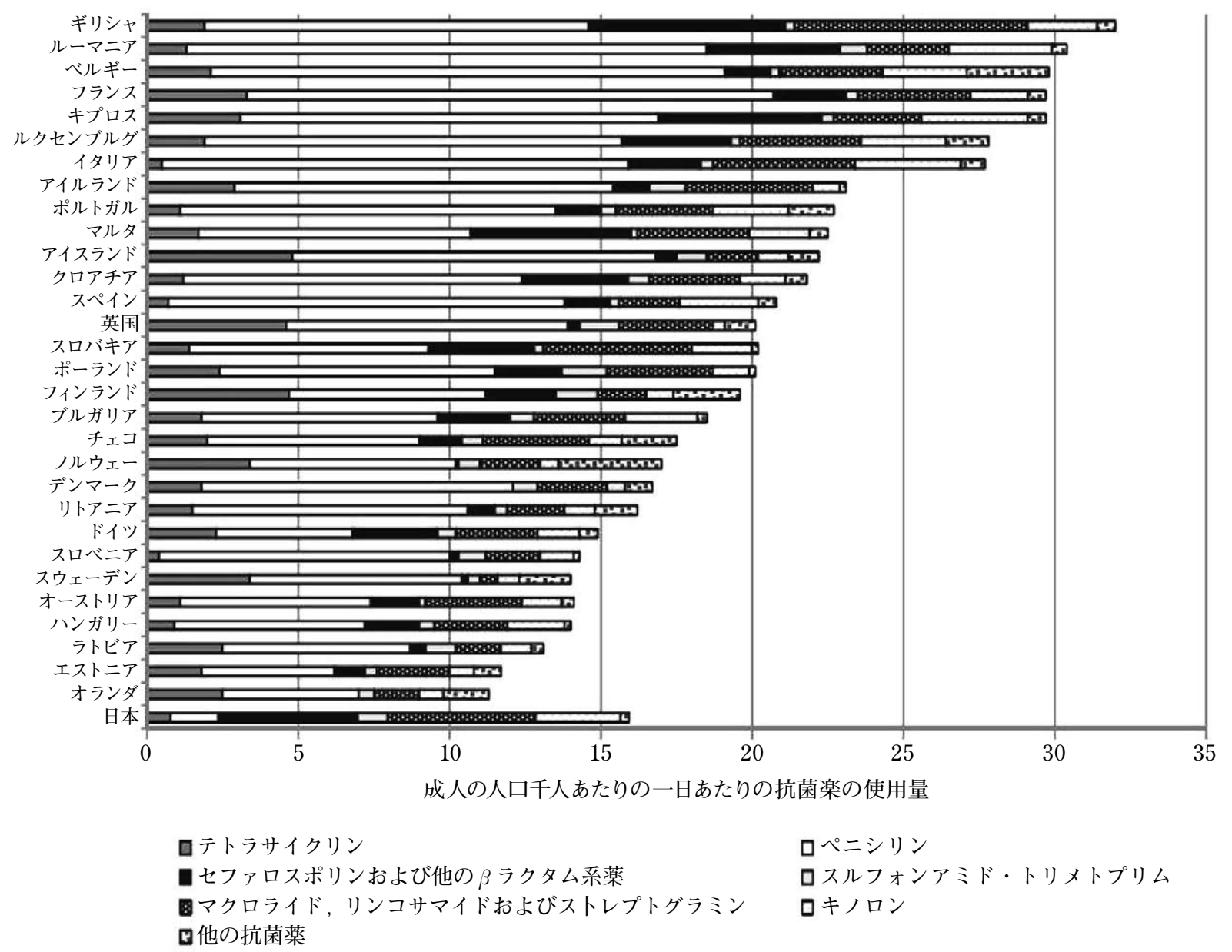

図 5 欧州および日本に打ける抗菌薬使用量の国際比較

http://www.mhlw.go.jp/file/06-Seisakujouhou-10900000-Kenkoukyoku/0000120769.pdf から引用

/0000120769.pdf. Accessed April 5, 2016.

3 ) Schaberle TF and Hack IM : Overcoming the current deadlock in antibiotic research. Tf' end. s Microbiol 22: 165-167, 2014.

4 ) The O'Neill Commission, UK : Antimicrobial Resistance: Tackling a crisis for health and wealth of nations. December p1-16. https://amr-review.org/sites/ default/files/AMR\%20Review\%20Paper\%20-\%20 Tackling\%20a\%20crisis\%20for\%20the $\% 20$ health $\% 20$ and\%20wealth\%20of\%20nations_1.pdf. Accessed July 2014

5 ) 国際的に妿威となる感染症対策関係閣僚会議: 薬剤耐 性アクションプラン概要 2016. http://www.mhlw.go.jp/ file/06-Seisakujouhou-10900000-Kenkoukyoku /0000120777.pdf. Accessed April 5, 2016.

6 ) WHO : Antimicrobial resistance : global report on surveillance 2014. April 2014.

7 ) 国立病院機構大阪医療センターに打けるメタロ $\beta$ - ラク タマーゼ（MBL）産生腸内細菌科の集積に関する外 部調査委員会: 国立病院機構大阪医療センターに打け るメタロ $\beta$-ラクタマーゼ (MBL) 産生腸内細菌科の集 積に関する外部調查報告. http://www.onh.go.jp/ict/
img/pdf/MBL_201601.pdf. Accessed February 10, 2016.

8 ) Kanayama A, Kawahara R, et al : Successful control of an outbreak of GES- 5 extended-spectrum $\beta$-lactamaseproducing Pseudomonas aeruginosa in a long-term care facility in Japan. J Hosp Infect 93: 35-41, 2016.

9 ) Walther-Rasmussen J and Høiby N : Class A carbapenemases. J Antimicrob Chemother 60: 470-482, 2007.

10) Dallenne C, Da Costa A, et al : Development of a set of multiplex PCR assays for the detection of genes encoding important beta-lactamases in Enterobacteriaceae. J Antimicrob Chemother 65: 490-495, 2010.

11）関東化学：シカジーニアス ${ }^{\circledR}$ 分子疫学解析 POT キット (緑膿菌用) http://www.kanto.co.jp/products/siyaku /pdf/s_mannual_pot_pseudo.pdf. 2016 年 12 月.

12) Yoneyama $T$, Yoshida $M$, et al : Oral care reduces pneumonia in older patients in nursing homes. J Am Geriatr Soc 50: 430-433, 2002.

13）国公立大学附属病院感染対策協議会：茵科における 院内感染ガイドライン改訂. 第 2 版, ビほう社, 東 京, 2015, 1-24 頁. 